\title{
THE ROLE OF SELF-REGULATED LEARNING ON STUDENTS’ ENGLISH ACHIEVEMENT
}

\author{
Ahmad Nadhif \\ State Institute of Islamic Studies (IAIN) Ponorogo \\ Email: nadheef@yahoo.com \\ Indah Rohmatika \\ State Institute of Islamic Studies (IAIN) Ponorogo \\ Email: indahrohmatika@gmail.com
}

\begin{abstract}
The objective of this study is to measure whether there is a significant influence of self-regulated learning (based on the theory of Barry J Zimmerman and Timothy Cleary) on the English achievement of the students in the first grade of MA Al-Islam Joresan Mlarak Ponorogo in Academic Year 2018/2019. This research applies an expost facto design, which uses questionnaires and documentation as the data collection technique. The data were analyzed through a simple linear regression formula by using SPSS 23.00 for windows. The finding shows a significant influence on self-regulated learning on the students' English learning achievement. The value of the F-test proved it was higher than F-table. F-test $41.615>$ F-table 3.19. The significance value was 0.000 , which was lower than 0.05 , and the equational regression model was $Y=81.551+0.145 \mathrm{X}$.
\end{abstract}

Abstrak: Penelitian ini bertujuan untuk mengukur apakah ada pengaruh yang signifikan dari self-regulated learning (berdasarkan teori Barry J Zimmerman and Timothy Cleary) terhadap prestasi Bahasa Inggris siswa MA Al-Islam Joresan Mlarak Ponorogo Tahun Pelajaran 2018/2019. Desain penelitian yang digunakan adalah ex-post facto, dengan populasi seluruh siswa kelas 1, dan sample sebanyak 148 siswa. Teknik sampling yang digunakan adalah Proportion-version Cochran. Data dikumpulkan dengan cara menyebar kuisioner dan mengumpulkan dokumentasi nailai raport, yang kemudian dianalisa dengan rumus regresi linear menggunakan SPSS 23.00 windows. Hasil penelitian menunjukkan bahwa terdapat pengaruh yang signifikan dari self-regulated learning terhadap prestasi Bahasa Inggris siswa. Hal ini dibuktikan dengan nilai F-test 41.615, yang lebih tinggi daripada F-table 3.19. Nilai signifikansinya adalah 0.000 , yaitu lebih rendah dari 0.05 ; dan persamaan model regresinya adalah $\mathrm{Y}=81.551+0.145 \mathrm{X}$.

Keywords: self-regulated learning; English learning achievement 


\section{INTRODUCTION}

Self-regulated learning is pervasive in today's educational research, and it is an umbrella term for various processes such as goal setting, metacognition, and self-assessment ${ }^{1}$. Although there is a non-linear relationship between invested effort and achieved learning outcomes ${ }^{2}$, some empirical studies show that selfregulated learning is an essential stimulus to academic achievement. ${ }^{3}$ In this regard, Demetriou et al. argue that an awareness of motivational and personality dispositions related to learning and relevant self-regulation skills will help maximize support and minimize hindrance to learning ${ }^{4}$. Previous research (for instance, Zimmerman 1989; Boekaerts 1999; Paris and Paris 2001) suggests that self-regulation impacts students learning in many ways.

Pintrich believes that the relationship between learners and their environment was mediated by self-regulatory activities, which influenced learners' achievements. ${ }^{5}$ As Schunk mentioned, Zimmerman asserts that learner's abilities and skills did not fully explain students' achievement, suggesting that self-regulation and motivation are important factors. Thus, self-regulation in learning is seen as a mechanism to help explain achievement differences among students and as a means to increase achievement. ${ }^{6}$ In Dignath and Veenman's words, citing Levin, the importance of self-regulated learning for academic and lifelong learning is a consensus?

${ }^{1}$ Loyens, Magda, and Rikers, "Self-Directed Learning in Problem-Based Learning and Its Relationships with Self-Regulated Learning." Educational Psychology Review, Vol. 20 No 4 (July, 2008), 411

2 Roelle, Carpenter, and Baars, "Synthesizing Cognitive Load and Self-Regulation Theory." Educational Psychology Review, vol 32 No.4 (October 2020), 907.

3 Alotaibi, Tohmaz, and Jabak, "The Relationship Between Self-Regulated Learning and Academic Achievement for a Sample of Community College Students at King Saud University." Education Journal ,Vol 6 No.1 (January, 2017), 30.

4 Demetriou, Spanoudis, and Mouyi, "Educating the Developing Mind.”. Educational Psychology Review, Vol 23 No. 4 (December, 2011), 646.

5 Schunk, "Self-Regulated Learning: The Educational Legacy of Paul R Pintrich," Educational Psychologist, 40 (2005), 86.

6 Schunk.

7 Dignath and Veenman, "The Role of Direct Strategy Instruction and Indirect Activation of Self-Regulated Learning-Evidence from Classroom Observation Studies."it is still poorly understood as to how teachers can most effectively support their students in enacting selfregulated learning. This article provides a framework about how self-regulated learning can be activated directly through strategy instruction and indirectly by creating a learning environment that allows students to regulate their learning. In examining teachers' instructional attempts for SRL, we systematically review the literature on classroom observation studies that have assessed how teachers support their students' SRL. The results of the 17 retrieved studies show that in most classrooms, only little direct strategy instruction took place. Nevertheless, some teachers provided their students with learning environments that require and thus foster self-regulated 
Besides, Zimmerman also argues that students' perceptions of themselves as learners and some various processes used to regulate learning are critical factors in academic achievement analyses. ${ }^{8}$ Moreover, as cited by Wigfield et al., Zimmerman, and Cleary state that students who can regulate their behavior in learning tend to achieve better in the learning process and have other positive outcomes in academic performance. ${ }^{9}$ Self-regulated learning is recognized as an important predictor of students' motivation and achievement. This process demands students to plan, monitor, and assess their learning independently. Self-regulated learning is essential to the learning process. Theoretically, it can help students create better learning habits, strengthen their study skills, apply learning strategies to enhance academic outcomes, monitor their performance, and evaluate their academic process. ${ }^{10}$

In this research, the researchers are eager to investigate whether the above scientific claims are also true in the Indonesian educational context, especially in a rural school like MA Joresan, Mlarak, Ponorogo. This study examines whether there is a significant influence of self-regulated learning on students' English learning achievement.

\section{RESEARCH METHOD}

This study was designed in the form of causal-comparative research. The researcher attempted to determine the cause, or reason, for existing differences in students' behavior or status by this design. In other words, established groups were already different on some variable, which could not be manipulated, and the researcher tried to recognize the main cause of this dissimilarity. Such research was occasionally called ex post facto, which was Latin for "after the fact," since both the effect and the alleged cause have already existed and must be studied in retrospect.

The population of this study was all first-grade students (241 students) of MA Al-Islam Joresan Mlarak from class A to Class J. Out of that population, through a simple random sampling technique, 148 students were selected as the sample.

learning indirectly. Based on a review of classroom observation studies, this article stresses the significance of (1, Educational Psychology Review, (July, 2020).

8 Zimmerman, "Self-Regulated Learning and Academic Achievement: an Overview." Educational Psychologist, Vol. 25 No. 1 (January, 1990),

9 Wigfield,Allan.,Klauda,Susan L., and Cambria, Jenna. "Influences on the Development of Academic Self-Regulatory Processes" Handbook of Self-Regulation of Learning and Performance,(March, 2011), 33.

${ }^{10}$ Zumbrunn, Tadlock, and Roberts, "Encouraging Self-Regulated Learning in the Classroom: A Review of the Literature.", VCU Scholars Compass (October, 2011), 5. 


\section{The instrument of Data Collection}

The instrument in this research used questionnaires to measure students' selfregulated learning and documentation of the students' scores at the previous final exam of English to measure their achievement.

The questionnaire was adapted from the theory developed by Zimmerman and Timothy J Cleary, as explained by Wentzel et al. ${ }^{11}$ consisting of 28 questions. Before distributing the questionnaire to the research participants, the researchers test its validity and reliability of 20 students who were not the sample of the study's subject. The result was as follows.

\section{Instrument Validity}

In this study, the researchers used SPSS 23.00 version to measure the validity. The analysis was used to determine the $r_{\mathrm{xy} ;}$ then it was consulted with $r_{\text {table }}$ with $5 \%$ significance level for product-moment with $d f$ or $d b$ is $n-r ; 20-2=18$. The $r_{\text {table }}$ was 0,444 . If the value of $r_{\text {xy }}$ was equal to or higher than the value of $r_{\text {table, }}$ it indicates that the item was valid. If the value of $r_{x y}$ is lower than the value of $r_{\text {table, }}$ it indicates that the item was invalid.

The validity test result showed that out of 28 items of the questionnaire proposed to 20 respondents, 22 were categorized as valid, then used as the research instrument of data collection.

\section{Reliability}

To test the reliability, the formula of Alpha Cronbach was applied. The result of the test showed that the reliability of the instrument was 0,913 . The value of reliability was counted with the " $\mathrm{r}$ " table on the significance of $5 \%$. The value of the " $r$ " table was 0,444 . Because the value of " $r$ " index reliability was 0,913 > " $r$ " table $(0,444)$, the test was therefore reliable.

\section{Data Analysis}

The collected data was then analyzed to decide whether or not there was a significant influence of self-regulated learning on first-grade students' English learning achievement at MA Al-Islam Joresan Mlarak in the academic year 2018/2019.

In this research, the data was analyzed through 2 types of tests: the assumption test and the hypothesis test. Before analyzing the data and the hypothesis, the researchers ensured that the data fulfill the assumption test requirement: normality and linearity and hypothesis test.

${ }^{11}$ Kathryn R Wentzel, Allan Wigfield. Handbook Of Motivation At School (New York: Rouledge, 2009), 247 


\section{Assumption Test}

The assumption test was categorized into two: normality and linearity tests. A normality test was a test of distribution normality (pattern) data. This normality test assumed that the data in each variable came from a normally distributed population. Several statistic tests could be used to test the normality of the data. In this research, the researcher used SPSS with the Kolmogorov-Smirnov formula.

The linearity test was a linear test of a regression line. It was used in simple linear regression analysis and multiple linear regression analysis. The linearity test was done by finding the regression line model from the independent variable $\mathrm{x}$ to the dependent variable $\mathrm{y}$. Based on the regression line model, linearity line regression could be tested.

\section{Hypothesis test}

To test the hypothesis, the researchers made use of regression analysis. There were two kinds of regression analysis: simple linear regression and multiple linear regressions. Because there were only two variables in this research, simple linear regression was selected to analyze the data, using SPSS program version 23.00 for windows.

\section{THE NATURE OF SELF-REGULATED LEARNING}

Self-regulation of learning activities is "a constant in the lives of students who must decide what to study, when to study, how long to study, and by what method to study." ${ }^{12}$ Henceforth, certain actions, such as selecting materials for restudy, allocating study time, and seeking help, withdrawing erroneous responses, ${ }^{13}$ are typical examples within the discussion of self-regulated learning. Many self-regulated learning models describe self-regulated learning as a cyclical process involving preparatory (planning), performance, and evaluation phases and involves cognitive, behavioral, motivational, and affective processes in each phase $^{14}$.

Simply put, self-regulated learning is defined by Nathan \& Goetz as "a form of acquiring knowledge and skills in which the learners are independent and self-motivated." In this regard, according to them, the learners autonomously

\footnotetext{
${ }^{12}$ Kornell and Bjork, "Optimising Self-Regulated Study." Memory Vol. 16 No.2 (2008), 125.

${ }^{13}$ van de Pol et al., "Mapping and Drawing to Improve Students' and Teachers' Monitoring and Regulation of Students' Learning from Text." Educational Psychology Review Vol. 32. No. 4. (August, 2020), 952.

${ }^{14}$ van Gog, Hoogerheide, and van Harsel, "The Role of Mental Effort in Fostering SelfRegulated Learning with Problem-Solving Tasks."technology, engineering, and mathematics Educational Psychology Review, Vol. 32 No 4. (July, 2020), 1056.
} 
select their achievement objectives and learning strategies that will lead them to achieve those goals. Learning can be modified and optimized by examining the effectiveness of one's learning strategies, comparing one's current state with the target state..$^{15}$

In the same line, Bandura and Zimmerman view self-regulation as selfgenerated thoughts, feelings, and actions planned and cyclically adapted to attaining personal goals. It is, according to them, and interaction of personal, behavioral, and environmental triadic processes. ${ }^{16}$

This self-regulation, according to Bandura, as cited by Alwisol, influences the learners' behavior by managing the learning environment, creating cognitive support, and evaluation. The ability of intelligence for symbolic thinking becomes a strong means to handle the environment, such as storing memory experience in verbal form and imagination for the behavior needs in the future. The ability to describe the desired potential result imaginatively, according to him, will increase the behavior strategy that leads toward the long-term goals. ${ }^{17}$

Murayama et al. state that self-regulation itself and other learning outcomes are partly due to curiosity and interest ${ }^{18}$. This conclusion is supported by many studies such as Sansone et al. (2010) ${ }^{19}$, Sansone et al. (2015) ${ }^{20}$, and Wigfield et al. $(2011)^{21}$

According to Bandura, as mentioned by Balapumi, human behavior is widely motivated and regulated by the ongoing exercise of self-influence. Humans have a self-management mechanism that leads them to control their cognition, motivation, and behavior proactively. Self-regulated learners are proactive in their learning efforts and are intrinsically motivated to increase their learning approach. Learners who can set appropriate goals, make appropriate plans and strategies to achieve their goals are called self-regulated learners. These learners continually reflect on their learning process's effectiveness, thus becoming aware

${ }^{15}$ Nathan and Goezt, Emotion, Motivation, and Self-Regulation: A Handbook for Teacher. (UK: Emerald, 2013), 126.

${ }^{16}$ Boekaerts, Pintrinch, and Zeidner, Handbook of Self-Regulation. (USA: Elsevier, 2005), 14.

${ }^{17}$ Alwisol, Psikologi Kepribadian. (Malang: UMM Press, 2009). 284.

${ }^{18}$ Murayama, FitzGibbon, and Sakaki, "Process Account of Curiosity and Interest."

${ }^{19}$ Sansone, Thoman, and Smith, "Interest and Self-Regulation:Understanding Individual Variability in Choices, Efforts, and Persistence over Time." In R. Hoyle (Ed.) Handbook of Personality and Self-Regulation (Malden, MA: Blackwell, 2010).

${ }^{20}$ Sansone, Thoman, and Fraughton, "The Relation Between Interest and Self-Regulation in Mathematics and Science." In Book Interest in Mathematics and Science Learning, 2015.

${ }^{21}$ Wigfield, Klauda, and Cambria, "Influences on the Development of Academic SelfRegulatory Processes,” 2011. 
of their strengths and limitations as learners and monitoring their behavior to improve effectiveness. ${ }^{22}$

As cited by Wigfield et al., Zimmerman et al. explain that in social cognitive models of self-regulation, there are separate phases of self-regulation: forethought and planning, performance monitoring, and reflections on performance. ${ }^{23}$

\section{Forethought Phase}

Forethought refers to self-regulatory processes that precede efforts to act and set the stage for it, such as goal setting and strategic planning. This self-regulatory phase is composed of two major categories: task analysis processes and sources of self-motivation beliefs. The former involves decomposing a learning task and its context into constituent elements and constructing a personal strategy from prior knowledge of these elements. It also involves two key parts: setting goals and strategic planning. The latter refers to a learner's beliefs about the effectiveness of their learning strategies and their personal skill in implementing during the regulatory phase, which emanates from four sources: self-efficacy, outcome expectations, task interest/value, and goal orientation.

\section{Performance Phase}

The key concept in the performance phase is self-control in terms of task strategies, self-instruction, imagery, time management, environmental structuring, helpseeking, and interest incentive.

Self-instruction involves overtly or covertly describing how to proceed as one executes a task, such as self-questioning as one reads textual material. Imagery involves forming mental pictures to assist learning and retention, such as converting textual information into visual tree diagrams, flow charts, and concept webs. Time management involvement is another performance process that has been improved by using strategies to estimate time requirements for the tasks. Environmental structuring refers to methods for optimizing the effectiveness of one's microenvironments. Help-seeking is a method of self-control that involves asking for assistance when learning or performing. And the interest incentives refers to one's interest in effort processes.

${ }^{22}$ Balapumi, "Factors and Relationships Influencing Self-Regulated Learning among ICT Students in Australian Universities.” (Curtin university: 2015) 19.

${ }^{23}$ Wigfield, Klauda, and Cambria, "Influences on the Development of Academic SelfRegulatory Processes," 2013.in Handbook of Self-Regulation of Learning and Performance, (March, 2011), 33. 


\section{Self-Reflection Phase}

The self-reflection phase is composed of two categories of response: self-judgments and self-reactions. The former refers to self-evaluating one's performance and attributing causal significance of the study. ${ }^{24}$ The key form of self-judgment is self-evaluation, which refers to comparing one's performance with a success standard or goal. Self-evaluative judgments are linked to causal attributive about the result, which is defined as beliefs about the causal implications of personal outcomes, such as one's fixed ability, effort, and strategy use. Meanwhile, the latter is composed of two key forms: self-satisfactions and adaptive or defensive inferences.

Self-satisfaction refers to feeling satisfaction or dissatisfaction with one's performance. Adaptive or defensive inferences are conclusions about how one needs to alter their self-regulatory approach during a subsequent effort to learn or perform.

\section{FINDINGS AND DISCUSSION}

This research's variables consisted of two variables: self-regulated learning $(\mathrm{X})$ and English learning achievement $(\mathrm{Y})$. The obtained data are described as follows.

\section{The Students' Self-Regulation of Learning}

As shown in Table 1, the questionnaire's result on how the research participants (148 students) self-regulate their learning shows that the highest score is 85 , and the lowest score is 40 . In this regard, the mean is 60.25 , the standard deviation is 10.388 , the variance is 107.917 , and the range is 45 .

\section{Table 1}

\section{Statistics descriptions of students' self-regulated learning questionnaire score}

\begin{tabular}{|l|l|l|}
\hline \multirow{2}{*}{$N$} & Valid & 148 \\
\cline { 2 - 3 } & Missing & 0 \\
\hline Mean & 60.25 \\
\hline Std. Error of Mean & .854 \\
\hline Median & 61.00 \\
\hline Mode & 66 \\
\hline Std. Deviation & 10.388 \\
\hline Variance & 107.917 \\
\hline Range & 45 \\
\hline Minimum & 40 \\
\hline
\end{tabular}

\footnotetext{
${ }^{24}$ Boekaerts, Pintrinch, and Zeidner, Handbook of Self-Regulation. (USA: Elsevier, 2005),
} 22. 


\begin{tabular}{|l|l|}
\hline Maximum & 85 \\
\hline Sum & 8917 \\
\hline
\end{tabular}

As for the frequency distribution, the result is presented in figure 1 below.

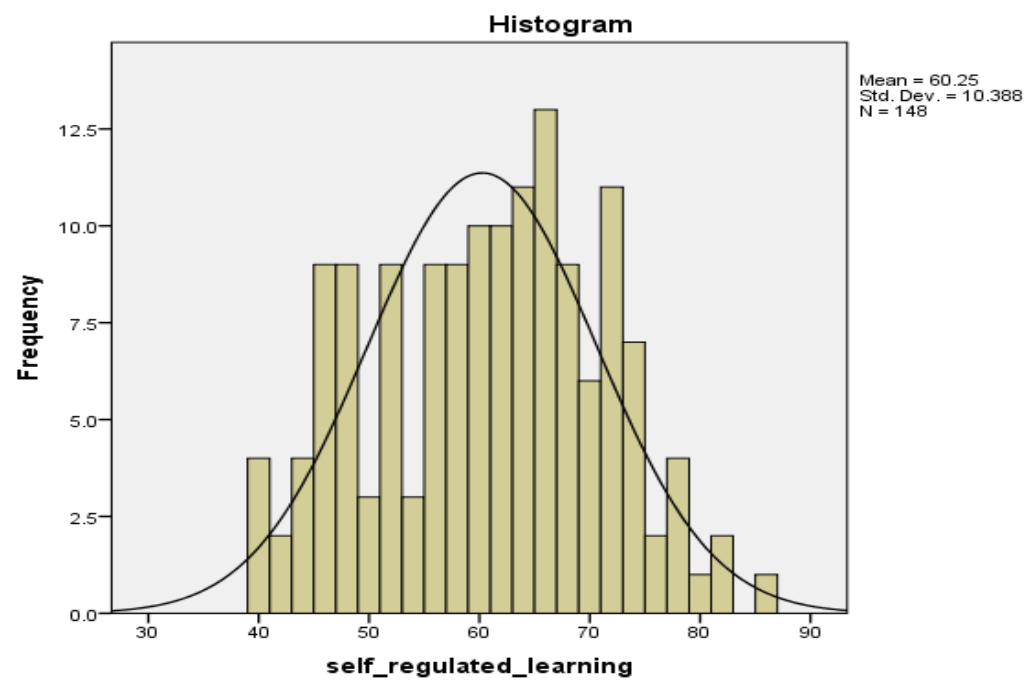

Figure 1. Histogram for the frequency distribution of the students' selfregulated learning

By the mean 60.25 and SD (deviation standard) 10.388, each score is then grouped by the following criteria.

a. More than $\mathrm{M}+1 . \mathrm{SD}(60.25+10.388=71)$ is categorized as good.

b. Between $M-1 . S D$ to $M+1 . S D(50-71)$ is categorized as medium.

c. Less than $\mathrm{M}-1 . \mathrm{SD}(60.25-10.388=50)$ is categorized as low.

Based on the above criteria, the following table is the students' score on their self-regulated learning, which shows that 28 students or $19 \%$ are categorized as good; 92 students or $62 \%$ are media, and 28 students or $19 \%$ are low.

Table 2

The categorization of students' self-regulated learning

\begin{tabular}{|c|l|c|c|l|}
\hline No. & \multicolumn{1}{|c|}{ Score } & Frequency & Percentage & Category \\
\hline 1. & More than 71 & 28 & $19 \%$ & Good \\
\hline 2. & $50-71$ & 92 & $62 \%$ & Medium \\
\hline 3. & Less than 50 & 28 & $19 \%$ & Low \\
\hline
\end{tabular}




\section{Students' English Learning Achievement}

The previous final examination showed that the highest score is 94 , and the lowest score was 85 , the mean is 90,33 , and the standard deviation was 3.214. Table 3 below shows a more detailed description of the examination result.

\section{Table 3}

\section{Statistics descriptions of students' English learning achievement score}

\begin{tabular}{|c|c|c|}
\hline \multicolumn{3}{|c|}{ Statistics } \\
\hline \multicolumn{3}{|c|}{ RESULT OF THE ENGLISH TEST } \\
\hline \multirow[t]{2}{*}{$\mathrm{N}$} & Valid & 148 \\
\hline & Missing & 0 \\
\hline \multicolumn{2}{|l|}{ Mean } & 90.33 \\
\hline \multicolumn{2}{|c|}{ Std. Error of Mean } & .264 \\
\hline \multicolumn{2}{|c|}{ Median } & 90.00 \\
\hline \multicolumn{2}{|l|}{ Mode } & 94 \\
\hline \multicolumn{2}{|c|}{ Std. Deviation } & 3.214 \\
\hline \multicolumn{2}{|c|}{ Variance } & 10.332 \\
\hline \multicolumn{2}{|l|}{ Range } & 9 \\
\hline \multicolumn{2}{|c|}{ Minimum } & 85 \\
\hline \multicolumn{2}{|c|}{ Maximum } & 94 \\
\hline \multicolumn{2}{|l|}{ Sum } & 13369 \\
\hline
\end{tabular}

Meanwhile, the frequency distribution of the test result is presented in table 4 below.

\section{Table 4}

Frequency distribution of students' English achievement

\begin{tabular}{|c|c|c|c|c|c|}
\hline \multicolumn{2}{|c|}{} & Frequency & Percent & Valid Percent & $\begin{array}{c}\text { Cumulative } \\
\text { Percent }\end{array}$ \\
\hline \multirow{7}{*}{ Valid } & 85 & 20 & 13.5 & 13.5 & 13.5 \\
\cline { 2 - 6 } & 87 & 14 & 9.5 & 9.5 & 23.0 \\
\cline { 2 - 6 } & 89 & 29 & 19.6 & 19.6 & 42.6 \\
\cline { 2 - 6 } & 90 & 30 & 20.3 & 20.3 & 62.8 \\
\cline { 2 - 6 } & 94 & 55 & 37.2 & 37.2 & 100.0 \\
\cline { 2 - 6 } & Total & 148 & 100.0 & 100.0 & \\
\hline
\end{tabular}

The table shows that the score of students' English learning achievement varies. There were 20 students or $13.5 \%$ of them score $85 ; 14$ students or $9.5 \%$ score $87 ; 29$ students or $19.6 \%$ score $89 ; 30$ students or $20.3 \%$ score 90 , and 55 
students or $37.2 \%$ score 94 . This data is presented in the form of a histogram in figure 2 below.

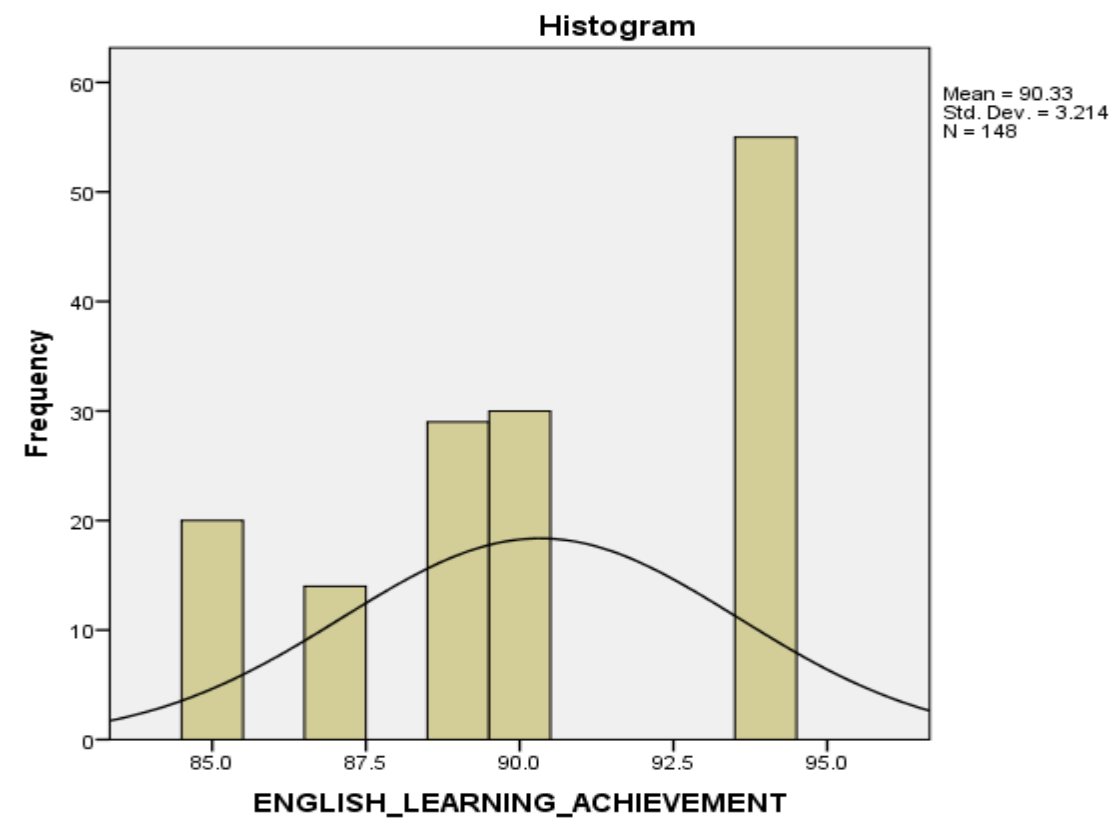

Figure 2. Histogram for documentation of English learning achievement

The score is categorized based on the following criteria:

a. More than $\mathrm{M}+1 . \mathrm{SD}(90.33+3.214=93)$ is categorized as good.

b. Between $M-1 . S D$ to $M+1 . S D(87-93)$ is categorized as medium.

c. Less than $\mathrm{M}-1 . \mathrm{SD}(90.33-3.214=87)$ is categorized as low.

Based on the criteria, the data (as shown in table 5 ) shows that $37.2 \%$ or 55 students in a good category, $49.3 \%$ or 73 students in a medium category, and $13.5 \%$ or 20 students in a low category. So, it can be concluded that many students have many medium English learning achievement. It can be seen from the total number of students who have medium English learning achievement are $49.3 \%$ or 73 students from 148 students.

Table 5

The categorization of students' English learning achievement

\begin{tabular}{|l|l|c|r|c|}
\hline No. & Score & Frequency & Percentage & Category \\
\hline 1. & More than 93 & 55 & $37.2 \%$ & Good \\
\hline 2. & $87-93$ & 73 & $49.3 \%$ & Medium \\
\hline 3. & Less than 87 & 20 & $13.5 \%$ & Low \\
\hline
\end{tabular}




\begin{tabular}{|l|l|l|l|l|}
\hline Total & & 148 & $100 \%$ & \\
\hline
\end{tabular}

\section{DATA ANALYSIS}

Before analyzing the data and coming to the hypothesis, the data have to fulfill the assumption test requirement, which consists of normality and linearity and hypothesis test. They are as follows.

\section{Assumption Test}

The final factor that we need to consider is the set of assumptions of the test.

\section{Normality test}

In this research, the researcher used SPSS with the Kolmogorov-Smirnov formula. The whole computation for the normality test is as follows.

\section{Table 6}

\section{Test of normality}

\begin{tabular}{|c|c|c|c|c|c|c|}
\hline \multirow{2}{*}{} & \multicolumn{3}{|c|}{ Kolmogorov-Smirnov $^{\mathrm{a}}$} & \multicolumn{3}{c|}{ Shapiro-Wilk } \\
\cline { 2 - 7 } & Statistic & $\mathrm{df}$ & Sig. & Statistic & $\mathrm{df}$ & Sig. \\
\hline VAR00001 & .070 & 148 & .073 & .980 & 148 & .030 \\
\hline \multicolumn{3}{|c|}{ a. Lilliefors Significance Correction } \\
\hline
\end{tabular}

The table above shows the significant value is 0.073 . The significant value is greater than 0.05 . It indicates that the test is normal in distribution.

\section{Linearity test}

The whole computation for the linearity test can be seen as follows.

\section{Table 7}

\section{Linearity test for English learning achievement and self-regulated learning}

\begin{tabular}{|c|c|c|c|c|c|c|c|}
\hline & & & $\begin{array}{l}\text { Sum of } \\
\text { Squares }\end{array}$ & df & $\begin{array}{l}\text { Mean } \\
\text { Square }\end{array}$ & $\mathrm{F}$ & Sig. \\
\hline \multirow{5}{*}{$\begin{array}{l}\text { english_ } \\
\text { learning_- } \\
\text { achievement } \\
\text { * self_ } \\
\text { regulated_ } \\
\text { learning }\end{array}$} & \multirow{3}{*}{ 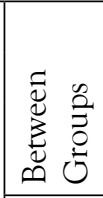 } & (Combined) & 701.845 & 36 & 19.496 & 2.649 & .000 \\
\hline & & \begin{tabular}{|l|} 
Linearity \\
\end{tabular} & 336.881 & 1 & 336.881 & 45.773 & .000 \\
\hline & & $\begin{array}{l}\text { Deviation from } \\
\text { Linearity }\end{array}$ & 364.964 & 35 & 10.428 & 1.417 & .088 \\
\hline & \multicolumn{2}{|c|}{ Within Groups } & 816.932 & 111 & 7.360 & & \\
\hline & \multicolumn{2}{|l|}{ Total } & 1518.777 & 147 & & & \\
\hline
\end{tabular}

Based on the table above, the deviation from linearity is 0.088 , which is higher than 0.05 . Hence, it can be concluded that this sample is linear in distribution. 


\section{Hypothesis Test}

The analysis of self-regulated learning on students' English learning achievement can be seen as follows.

Table 8

\section{Model summary of simple linear regression}

\begin{tabular}{|c|c|c|c|c|c|c|c|c|c|}
\hline \multicolumn{10}{|c|}{ Model Summary } \\
\hline \multirow[b]{2}{*}{$\begin{array}{l}\overline{0} \\
\frac{0}{0} \\
\sum^{0}\end{array}$} & \multirow[b]{2}{*}{$\simeq$} & \multirow[b]{2}{*}{ 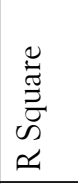 } & \multirow{2}{*}{$\begin{array}{l}\text { Adjusted } \\
\text { R Square }\end{array}$} & \multirow{2}{*}{$\begin{array}{l}\text { Std. The } \\
\text { error } \\
\text { of the } \\
\text { Estimate }\end{array}$} & \multicolumn{5}{|c|}{ Change Statistics } \\
\hline & & & & & $\begin{array}{l}\text { R Square } \\
\text { Change }\end{array}$ & $\begin{array}{l}\mathrm{F} \\
\text { Change }\end{array}$ & $\mathrm{df} 1$ & $\mathrm{df} 2$ & \begin{tabular}{|ll} 
Sig. F \\
Cha \\
nge
\end{tabular} \\
\hline 1 & $.471^{\mathrm{a}}$ & .222 & .216 & 2.845 & .222 & 41.615 & 1 & 146 & .000 \\
\hline \multicolumn{10}{|c|}{ a. Predictors: (Constant), self_regulated_learning } \\
\hline \multicolumn{10}{|c|}{ b. Dependent Variable: english_learning_achievement } \\
\hline
\end{tabular}

Based on the table above, the value $R$ as the symbol of coefficient correlation shows a score of 0,471 . It means that the correlation between the two variables is moderate. Moreover, the value of $R$-square/coefficient determinations informs how well the independent and dependent variables interact. The $R$-square above is 0.222 . It implies that the independent variable (self-regulated learning) gives $22.2 \%$ contribution to the dependent variable (English learning achievement), then $77.8 \%$ is influenced by other factors.

The analysis then focuses on each variable's linearity, namely the independent variable X (self-regulated learning) toward the dependent variable Y (English learning achievement), as presented in the ANOVA table below.

Table 9

ANOVA table

\begin{tabular}{|c|c|c|c|c|c|c|}
\hline \multicolumn{2}{|c|}{ Model } & Sum of Squares & $\mathrm{df}$ & Mean Square & $\mathrm{F}$ & Sig. \\
\hline \multirow[t]{3}{*}{1} & Regression & 336.881 & 1 & 336.881 & 41.615 & $.000^{\mathrm{b}}$ \\
\hline & Residual & 1181.897 & 146 & 8.095 & & \\
\hline & Total & 1518.777 & 147 & & & \\
\hline
\end{tabular}

Referring to the ANOVA table above, the F-test is 41.615, which higher than F-table 3.91. F-table with $d f 1=1, d f 2=146$ listed 3.91. The significant value is 0,000 . It means that the regression model equation is significant because it has already fulfilled the criteria of linearity. The criteria are that if the significant value (less than) $<0.05$, linear regression can be applied. 
After that, the analysis focuses on the independent variable $\mathrm{X}$ (self-regulated learning) toward the dependent variable Y (English learning achievement). It is presented in the coefficient table below.

Table 10

Coefficients table

\begin{tabular}{|c|c|c|c|c|c|c|}
\hline & \multirow{2}{*}{$\begin{array}{c}\text { Model } \\
\text { B }\end{array}$} & \multicolumn{2}{|c|}{$\begin{array}{c}\text { Unstandardized } \\
\text { Coefficients }\end{array}$} & $\begin{array}{c}\text { Standardized } \\
\text { Coefficients }\end{array}$ & \multirow[t]{2}{*}{$\mathrm{t}$} & \multirow[t]{2}{*}{ Sig. } \\
\hline & & Std. Error & Beta & & & \\
\hline \multirow[t]{2}{*}{1} & (Constant) & 81.551 & 1.381 & & 59.053 & .000 \\
\hline & $\begin{array}{l}\text { self_regulated_ } \\
\text { learning }\end{array}$ & .146 & .023 & .471 & 6.451 & .000 \\
\hline
\end{tabular}

Table 10 above gives a clear description of the equation regression model through unstandardized coefficients $\mathrm{B}$. The equation regression model is $\mathrm{Y}=81.551+0.146 \mathrm{X}$. The $t$-score is 6.451 . When compared to $T$-table with a $5 \%$ level of significance, it is 1.97. It means the T-score is higher than the T-table. Meanwhile, the significant value is 0,000 . It means that the equation regression is significant because it already fulfills the criteria of linearity.

Based on the result above, it is concluded that $\mathrm{Ha}$ is accepted and $\mathrm{HO}$ is rejected. It implies, therefore, that self-regulated learning significantly influences the students' English learning achievement. The ANOVA table shows, the F-test is 41.615 and the F-table 3.91. F-table with $d f 1=1, d f 2=146$ listed 3.91. It means that F-test is higher than F-table. Therefore, the Null hypothesis (H0) is rejected, and the alternative hypothesis is accepted. Besides, the equal regression model is $\mathrm{Y}=81.551+0.146 \mathrm{X}$. And sig. value 0.000. $(\mathrm{P}<0.05)$. Ha is therefore accepted, and $\mathrm{HO}$ is rejected. The $R$-square is 0.222 , implying that the independent variable (self-regulated learning) gives a $22.2 \%$ contribution to the dependent variable (English learning achievement).

\section{CONCLUSION}

This study aims to measure whether there is a significant impact of self-regulated learning (based on the theory of Barry J Zimmerman and Timothy Cleary) on the students' English a chievement in the first grade of MA Al-Islam Joresan Mlarak Ponorogo in Academic Year 2018/2019. This ex post facto research proves a significant influence on how the students' self-regulation in learning on their English achievement. Therefore, more evidence on how important for teachers, whose role in guiding their students' success in learning, is undeniably essential, to help make their students self-regulate their learning inside and outside the classroom, for example,e by arousing their interest and curiosity on the subject matter. 


\section{REFERENCES}

Alotaibi, Khaled, Riyad Tohmaz, and Omar Jabak. "The Relationship Between Self-Regulated Learning and Academic Achievement for a Sample of Community College Students at King Saud University." SSRN Electronic Journal, 2017. https://doi.org/10.2139/ssrn.3444622.

Alwisol. Psikologi Kepribadian. Malang: UMM Press, 2009.

Balapumi, Rohini. "Factors and Relationships Influencing Self-Regulated Learning among ICT Students in Australian Universities,” n.d., 287.

Boekaerts, M. "Self-Regulated Learning: Where We Are Today." International Journal of Educational Research 31 (1999). https://doi.org/10.1016/ S0883-0355(99)00014-2.

Boekaerts, Monique, Paul R Pintrinch, and Moshe Zeidner. Handbook of SelfRegulation. Elsevier, 2005.

Demetriou, Andreas, George Spanoudis, and Antigoni Mouyi. "Educating the Developing Mind: Towards an Overarching Paradigm." Educational Psychology Review 23, no. 4 (December 2011): 601-63. https://doi. org/10.1007/s10648-011-9178-3.

Dignath, Charlotte, and Marcel V. J. Veenman. "The Role of Direct Strategy Instruction and Indirect Activation of Self-Regulated Learning-Evidence from Classroom Observation Studies." Educational Psychology Review, July 15, 2020. https://doi.org/10.1007/s10648-020-09534-0.

Gog, Tamara van, Vincent Hoogerheide, and Milou van Harsel. "The Role of Mental Effort in Fostering Self-Regulated Learning with Problem-Solving Tasks." Educational Psychology Review 32, no. 4 (July 2020): 1055-72. https://doi.org/10.1007/s10648-020-09544-y.

Kornell, Nate, and Robert A. Bjork. "Optimising Self-Regulated Study: The Benefits-and Costs-of Dropping Flashcards." Memory 16, no. 2 (February 2008): 125-36. https://doi.org/10.1080/09658210701763899.

Loyens, Sofie M. M., Joshua Magda, and Remy M. J. P. Rikers. "Self-Directed Learning in Problem-Based Learning and Its Relationships with SelfRegulated Learning." Educational Psychology Review 20, no. 4 (July 2008): 411-27. https://doi.org/10.1007/s10648-008-9082-7. 
Murayama, Kou, Lily FitzGibbon, and Michiko Sakaki. "Process Account of Curiosity and Interest: A Reward-Learning Perspective." Educational Psychology Review 31, no. 4 (December 2019): 875-95. https://doi. org/10.1007/s10648-019-09499-9.

Nathan, Hall, and Thomas Goezt. Emotion, Motivation, and Self-Regulation: A Handbook for Teacher, 2013.

Paris, Scott, and Alison H. Paris. "Classroom Applications of Research on SelfRegulated Learning.” Educational Psychologist 36, no. 2 (June 2001): 89101. https://doi.org/10.1207/S15326985EP3602_4.

Pol, Janneke van de, Mariëtte van Loon, Tamara van Gog, Sophia Braumann, and Anique de Bruin. "Mapping and Drawing to Improve Students' and Teachers' Monitoring and Regulation of Students' Learning from Text: Current Findings and Future Directions." Educational Psychology Review 32, no. 4 (December 2020): 951-77. https://doi.org/10.1007/s10648-02009560-y.

Rijal, Fakhrul, and Tasnim Idris. “Teachers' Pedagogic Competence In Utilizing Learning Media Of Islamic Religious Education At State Junior High Schools In Lhoksuemawe." Cendekia 18, no. 1 (2020): 101-16.

Roelle, Julian, Shana K. Carpenter, and Martine Baars. "Synthesizing Cognitive Load and Self-Regulation Theory: A Theoretical Framework and Research Agenda." Educational Psychology Review 32, no. 4 (December 2020): 90315. https://doi.org/10.1007/s10648-020-09576-4.

Sansone, C., D.B Thoman, and J.L. Smith. "Interest and SelfRegulation:Understanding Individual Variability in Choices, Efforts, and Persistenceover Time." In In R. Hoyle (Ed.) Handbook of Personality and Self-Regulation, 192-217. Malden, MA: Blackwell, 2010.

Sansone, Carol, Dustin Thoman, and Tamra Fraughton. "The Relation Between Interest and Self-Regulation in Mathematics and Science." In Interest in Mathematics and Science Learning, 111-31, 2015.

Schunk, Dale H. "Self-Regulated Learning: The Educational Legacy of Paul R. Pintrich.” Educational Psychologist 40, no. 2 (June 2005): 85-94. https:// doi.org/10.1207/s15326985ep4002_3.

Wigfield, Allan, Susan L. Klauda, and Jenna Cambria. "Influences on the Development of Academic Self-Regulatory Processes." In Handbook of Self- 
Regulation of Learning and Performance. Routledge, 2011. https://doi. org/10.4324/9780203839010.ch3.

—. "Influences on the Development of Academic Self-Regulatory Processes." In Handbook of Self-Regulation of Learning and Performance. Routledge, 2013. https://doi.org/10.4324/9780203839010.ch3.

Zimmerman, Barry J. "A Social Cognitive View of Self-Regulated Academic Learning.” Educational Psychology 81 (1989): 329-339. https://doi. org/10.1037/0022-0663.81.3.329.

_. "Self-Regulated Learning and Academic Achievement: An Overview." Educational Psychologist 25, no. 1 (January 1990): 3-17. https://doi. org/10.1207/s15326985ep2501_2.

Zumbrunn, Sharon, Joseph Tadlock, and Elizabeth Danielle Roberts. "Encouraging Self-Regulated Learning in the Classroom: A Review of the Literature," n.d., 29. 